\title{
Virtuelle ting - Kan virtuelle ting strafferetligt karakteriseres eller sidestilles som rørlige ting?
}

\author{
Af Peter Dueholm Mathiasen ${ }^{1}$
}

\begin{abstract}
The article discusses whether virtual items can be considered "rørlige ting" (movable objects) thereby subject to protection against, e.g., theft under the Danish Criminal Code. Norwegian, Swedish and Dutch criminal laws are included in the article.
\end{abstract}

\section{Indledning}

I nyere tid anvendes begrebet »virtuel« ofte i forbindelse med fænomener, der fremstår i digital form via computerteknologien, men som i en række henseender fungerer på samme måde som $\mathrm{i}$ den fysiske verden.

En virtuel verden simulerer en mere eller mindre virkelig verden for brugerne. Uanset det konkrete indhold i den virtuelle verden er der tale om en parallelverden af billeder og lyd, som er skabt af mennesker og gengivet på en flerhed af computere.

Verden over bruger millioner af mennesker hver dag adskillige timer på virtuelle verdener. De investerer deres tid og penge på at opbygge, vedligeholde og udvikle deres virtuelle person, hjem og ejendele. Verdensbanken har anslået, at de virtuelle verdener globalt set omsatte for 8.500 millioner dollars (USD) i år 2007. Verdensbanken har tillige skønnet, at omsætningen steg til 21,2 milliarder dollars (USD) i år 2012. ${ }^{2}$ Dertil kommer et marked bestående af en række sekundære, uautoriserede forhandlere af virtuelle ting og tjenesteydelser. Det sidstnævnte marked, som udfører sine aktiviteter uden kontrol og ledelse fra udviklerne af de virtuelle verdener, omsætter årligt varer for 3,023 milliarder dollars (USD) til brugerne. ${ }^{3}$

I oktober 2010 anslog udvikleren af den største (målt på antal betalende brugere) virtuelle verden, at ca. $5 \%$ af alle danskere havde en brugerkonto hos dem. ${ }^{4}$

* Title in English: Virtual items - Can virtual items be characterized or equated as movable objects in a criminal law context? 
Ifølge sikkerhedsfirmaet Kaspersky, der bl.a. følger udviklingen inden for spilrelateret it-kriminalitet, er det sorte marked for virtuelle ting steget kraftigt $\mathrm{i}$ de seneste år, hvilket blandt andet skyldes muligheden for at få omsat virtuelle ting til en fysisk anerkendt valuta. ${ }^{5}$

De betydelige personlige og økonomiske ressourcer, som involveres i virtuelle verdener, gør det relevant at forholde sig juridisk til, hvordan en række forhold skal indplaceres i samfundets sædvanlige retsregler.

Temaet for denne artikel er derfor, om de berigelsesforbrydelser, der angiver eller sidestiller objektet for forbrydelsen som en »rørlig ting" (Danmark), »en gjenstand « eller »en løsøregjenstand « (Norge), kan omfatte handlinger, der er rettet mod virtuelle ting: Hvis en bruger af en virtuel verden opsøger en anden brugers virtuelle hjem og uden samtykke borttager noget, der befinder sig heri, er der da tale om tyveri? Hvis man udlåner en virtuel ting til en anden bruger, og vedkommende efterfølgende uberettiget sælger den til en tredjemand, er der da tale om underslæb? Hvis man i den fysiske verden ved trussel om øjeblikkelig anvendelse af vold aftvinges en virtuel ting, er der da tale om røveri?

\section{Den hollandske højesteret}

Den hollandske højesteret konkluderede i 2012, at en virtuel amulet og en virtuel maske måtte anses for ting, som kan være genstand for tyveri i medfør af artikel 310 i Wetboek van Strafrecht. ${ }^{6}$ Den hollandske tyveribestemmelse lyder: »Den, der fjerner ting, som helt eller delvist tilhører en anden person, med den hensigt ulovligt at tilegne sig tingen, er skyldig i tyveri[...] . $^{7}$

Dommen vedrørte et tilfælde, hvor en 13-årig dreng blev truet med en (fysisk) kniv til at logge ind på sin konto $i$ en virtuel verden og dernæst udlevere de nævnte virtuelle ting til gerningsmændene.

Domstolen tog bl.a. stilling til, om virtuelle ting er beskyttet som »ting« eller »data " og udtalte, at selvom de i sagen omhandlende virtuelle ting består af bits og bytes, er de »ting«, som er beskyttet mod tyveri. ${ }^{8}$ Domstolen lagde bl.a. vægt på, at de virtuelle ting har en formueværdi, at ofret havde eksklusiv kontrol over objekterne, og at ofret mistede denne kontrol, da de tiltalte tilegnede sig objekterne.

\section{Legalitetsprincippet}

Legalitetsprincippet, nulla poene sine lege, blev i Danmark bekræftet ved straffeloven af 1866. Indtil da anerkendtes en mulighed for ved dom at erklære en handling for strafbar pga. friere overvejelser om bl.a. handlingens »naturlige strafværdighed« eller dens modstrid med en lovs »ånd og grundsætninger«. Domstolenes 
retsskabende funktion var en konsekvens af enevælden, hvorunder Højesteret kunne anvende kongens beføjelser til at supplere lovene.

I år 1912 bemærkede Straffelovskommissionen, at det forhåbentligt ville vise sig, at et nyt udkast til straffelovens specielle del fremtrådte i en mere fuldstændig skikkelse end straffeloven af 1866. Kommissionen udtalte dog samtidig, at det ikke kunne antages, at udkastet var »saa udtømmende, at der ikke vil blive Brug for Analogi, [...] navnlig naar Hensyn tages til den evige Fornyelse af Retsforholdenes Fremtrædelsesformer «. ${ }^{9}$

Det fremgår af den danske straffelovs $\S 1$, at »straf kan kun pålægges for et forhold, hvis strafbarhed er hjemlet ved lov, eller som ganske må ligestilles med et sådant«. Den tilladelige analogi skal derfor være en fuldstændig analogi. Det betyder, at tilfældet skal have en høj grad af lighed med lovens forhold, og der skal i alt væsentligt være lige så stærke grunde til at straffe. ${ }^{10}$

Flere danske straffebestemmelser er formuleret ved brug af almene begreber og udtryk. Det samme gælder flere strafbestemmelser fra de øvrige nordiske lande. Eksempelvis vedrører den norske straffelov $1902 \S 257$ »en gjenstand«. Den svenske straffelovs kapitel $8, \S 1$ udtrykker handlingen i den generelle vending: $»[\ldots]$ tager vad annan tilhör [...] «. Sådanne formuleringer forudsætter, at der ved den konkrete retsanvendelse sker en fortolkning, hvor det fx må afgrænses hvilke fænomener, der er omfattet af det pågældende delikt. I nærværende sammenhæng er spørgsmålet derfor, hvorvidt en række eksisterende straffebestemmelser er direkte anvendelige på virtuelle ting. For at kunne besvare dette spørgsmål må der tages stilling til, om virtuelle ting er omfattet af de deskriptive udtryk, som straffeloven anvender.

\subsection{Dansk retspraksis $i$ sager der involverer nye teknologiske fonomener}

I Danmark har domstolene har ikke ført en entydig praksis med hensyn til betydningen af analogiforbuddet i relation til nye teknologiske fænomener. Undertiden har domstolene fortolket udvidende for at ramme kriminalitetsformer, hvis strafværdighed ganske svarer til gerningsindholdet i en bestemmelse, som ellers ikke har taget hensyn til den teknologiske udvikling. I U1940.156Ø blev en person straffet efter analogien i straffelovens $\S 263$, der dengang alene omfattede retsstridige brevåbninger. Tiltalte havde foretaget aflytning af en telefonsamtale gennem tilslutning af en skjult lytteanordning. Ved Østre Landsrets dom af 13. februar 1995 fandtes disketter ikke at være omfattet af skriftlighedskravet i straffelovens $§ 163$ eller dennes analogi. Omvendt fandt retten i U1996.356Ø, at den omstændighed, at kommunikationen i et vist omfang skete ved anvendelse af di- 
sketter ikke udelukkende de at anvende lov om offentlige indsamlinger $\S 2$. Fremgangsmåden ansås som kædebreve i lovens forstand. ${ }^{11}$

Det er på denne baggrund dristigt at have klare forventninger til, hvordan danske domstole vil fortolke de eksisterende straffebestemmelser i henseende til objekter i virtuelle verdener - særligt fordi det ikke tidligere har været overvejet, om virtuelle ting i en strafferetlig sammenhæng er »ting«, »oplysninger«, »energimængder« eller noget helt fjerde.

\section{Virtuelle ting}

De objekter, som i denne artikel omtales som »virtuelle ting «, adskiller sig fra andre digitale objekter ved, at de kun kan lagres på it-udstyr, der er opstillet hos udvikleren af den virtuelle verden, og at de virtuelle ting er lagret på en sådan måde, at varetægtsforholdet ændres, hvis den virtuelle ting bemægtiges af en anden bruger.

Det er karakteristik for virtuelle ting, at de har afgørende ligheder med almindeligt løsøre. Nedenfor følger fem væsentlige fællestræk:

1) Når en bruger har en virtuel ting i sin besiddelse, kan andre brugere ikke besidde den samme virtuelle ting på samme tid.

2) Brugeren er kun begrænset af lovgivningen og eventuelle private viljeserklæringer i forhold til, hvordan han kan bruge den virtuelle ting. Brugeren kan derfor som udgangspunkt selv afgøre, hvordan han vil anvende den virtuelle ting, herunder bl.a. om han vil forbruge, ødelægge eller bortskaffe den.

3) Brugeren kan nægte andre at bruge den virtuelle ting, ligesom han midlertidigt eller permanent kan tillade andre at bruge den.

4) Brugeren kan overdrage den virtuelle ting til andre brugere, og en eventuel fortjeneste forbundet hermed kan tilfalde overdrageren.

5) Under normale driftsbetingelser er der som udgangspunkt ingen grænse for, hvor længe brugeren kan besidde den pågældende virtuelle ting. ${ }^{12}$

I det følgende anvendes begrebet »virtuelle ting« om fænomener, som har disse fem karakteristika.

\subsection{Data og information}

Virtuelle ting kan både beskrives som information og data. Information kan meget forenklet defineres som det betydningsindhold, der tillægges en given mængde data, og som kan opfattes med de menneskelige sanser. Når data er bearbejdet eller fortolket, er der således tale om information. ${ }^{13}$ Hvis aftaleretlige dispositio- 
ner udelades, ${ }^{14}$ kan den information, som et menneske har erkendt, ikke underkastes fremmed menneskelig kontrol og herredømme. Uafhængigt af et medie kan information derfor ikke bemægtiges med de handlinger, som berigelsesforbrydelserne kriminaliserer. ${ }^{15}$ En eventuel beskyttelse af information må derimod findes andetsteds, fx i immaterialretlige regler.

Data betegner ufortolkede kendsgerninger; ofte repræsenteret ved tal og bogstaver. I et it-system er data repræsenteret ved et maskinlæsbart signal, og betegner den kommunikation som overføres mellem computerenheder. Hvis data har et menneske som adressat, sker der en præsentation, der kan opfattes med de menneskelige sanser af den information, som data bærer. Når en bruger af en virtuel verden får præsenteret en virtuel ting i billede og lyd, er der således tale om information. Data bærer i dette tilfælde informationen fra udviklerens server til brugeren. Data kan derfor beskrives som et medie ${ }^{16}$ mellem informationsafsender og informationsmodtager. Data fungerer i situationen som medie på linje med traditionelle medier, der anvendes til at lagre og formidle andre informationsprodukter som fx bøger, tidsskrifter mv. ${ }^{17}$ Beskyttelsen af information er noget andet end beskyttelsen af mediet, in casu data. Data, der udgør en virtuel ting, kan bemægtiges med de handlinger, som berigelsesforbrydelserne kriminaliserer. Det skyldes, at den samme virtuelle ting ikke kan besiddes af flere personer på samme tid, jf. den ovenstående karakteristik af virtuelle ting.

\subsection{Ejendomsretten over data}

Forudsætningen for at der kan udføres en handling, der resulterer i en uberettiget vinding direkte gennem retsstridig tilføjelse af et tilsvarende formuetab er, at det pågældende objekt kan ejes. Forudsætningen kan tillige udledes af, at objektet $\mathrm{i}$ Danmark er angivet som en »fremmed rørlig ting«, i Norge »en gjenstand som helt eller delvis tilhører en annen« og i Sverige »tager vad annan tilhör med uppsåt att tillägna sig det«. Heri ligger, at tingen helt eller delvist skal tilhøre en anden end gerningsmanden. Der ydes derfor ikke beskyttelse til ejerløse ting dvs. ting, der enten konkret ikke ejes af nogen, eller generelt slet ikke kan ejes. Det er således en forudsætning, at den pågældende virtuelle ting er ejet af en person.

Stiftelsen af ejendomsretten over objekter giver ejeren nogle eksklusive beføjelser til at råde over det, som ejendomsretten angår. ${ }^{18}$ Beføjelsen til at råde over objektet kan være fuldstændig hhv. begrænset. Den fuldstændige ejendomsret er kendetegnet ved, at ejeren i enhver henseende kan råde over objektet ved faktiske og retlige dispositioner. Ejendomsretten må dog respektere de indskrænkninger, der følger af love, aftaler mv. Ejendomsretten er følgelig blevet defineret negativt 
som beføjelsen til at råde i enhver henseende med de indskrænkninger, der følger af lov, almindelige retsgrundsætninger mv.

Det er derfor en betingelse, at erhvervelsen af en virtuel ting er forbundet med, at brugeren tildeles en ret til uforstyrret at råde over den pågældende virtuelle ting med respekt for eventuelle begrænsninger som følge af private viljeserklæringer, love mv., før den virtuelle ting kan siges at være ejet af brugeren.

\subsubsection{Individualitet og kontrol}

For at noget kan ejes, må det eksistere som et individualiseret fænomen, der kan kontrolleres. De verber, som anvendes i delikterne, forudsætter således også, at handlingen retter sig mod objekter, der er afgrænset på en sådan måde, at de består som et individualiseret objekt. Det giver kun mening at anvende verber som »borttager«, »tilegner« osv. om handlinger, hvor objektet foreligger som et afgrænset, individuelt fænomen. Det hænger sammen med, at objektet skal kunne kontrolleres, før det kan være genstand for de handlinger, som udtrykkes af verberne i bestemmelserne. Eksempelvis kan solens stråler i sin umiddelbare form hverken individualiseres eller kontrolleres, og det savner derfor mening, at anvende de verber, som fremgår af delikterne, på solens stråler. Disse kan i ukontrolleret form hverken borttages, tilegnes eller aftvinges af nogen. ${ }^{19}$ Teknologiske indretninger gør, at den energi, som findes i solens stråler kan individualiseres og kontrolleres, således at den fx kan indgå som energikilde i den almindelige elforsyning. I denne form er der tale om et objekt, der kan udsættes for de handlinger, som beskrives i delikterne. Det samme gælder en lang række andre objekter, som kendes fra samhandlen: Visse bakterier sælges til mejeriindustrien og til farmaceutisk brug, kildevand omsættes som læskedrik og luft sælges bl.a. som rengøringsartikler og havariudstyr til biler. ${ }^{20}$ Det er et fællestræk ved disse objekter, at de (dvs. indholdet) er bragt under kontrol, og at de følgelig kan bemægtiges med de handlinger, som verberne udtrykker i delikterne. Muligheden for at kunne kontrollere objektet er derfor afgørende. Hvis objektet er bragt under kontrol, kan det ejes af en person.

Eftersom det er en forudsætning, at objekter kan kontrolleres og ejes, før disse er omfattet af den strafferetlige beskyttelse, må det drøftes, hvornår disse betingelser er opfyldt i relation til virtuelle ting.

De objekter, der foreligger i en kontrollerbar form i virtuelle verdener, er kendetegnet ved, at brugerne potentielt kan råde eksklusivt over objektet ved faktiske og retlige dispositioner. Når en brugeren har fremstillet, fundet eller fået overdraget en virtuel ting, har brugeren de eksklusive beføjelser, som kendetegnes ved ejendomsretten. Brugeren kan således eksklusivt benytte den virtuelle ting, som 
han behager, herunder nægte at andre kan bruge denne (faktiske dispositioner). Han kan tillige vælge at overdrage den virtuelle ting til andre, fx som led i en byttehandel (retlige dispositioner), og først da vil den eksklusive mulighed for at råde over den virtuelle ting blive overdraget til en anden person. Virtuelle ting, der foreligger i en kontrollerbar form, kan derfor potentielt være undergivet ejendomsret. Brugerens ret til at udøve de nævnte beføjelser over sine virtuelle ting kan under normale driftsbetingelser kun forstyrres med de retsstridige handlinger, som berigelsesforbrydelserne kriminaliserer.

\subsubsection{De retsstiftende kendsgerninger}

Ejendomsretten til virtuelle ting kan opstå ved, at brugeren selv skaber det data, der udgør den pågældende virtuelle ting. Flere virtuelle verdener giver brugerne mulighed for at udvikle objekter, som herefter kan bruges i den virtuelle verden. ${ }^{21}$ Der er tale om en originær retserhvervelse, dvs. en ret over det pågældende objekt, der udspringer af, at man selv har frembragt det.

Ejendomsretten kan tillige opstå ved, at brugeren tager et ejerløst objekt til sig. Det kan fx forekomme i situationer, hvor en (anden) bruger har opgivet ejendomsretten til en virtuel ting. Det forekommer ikke sjældent $\mathrm{i}$ virtuelle verdener, at brugerne kun kan besidde et begrænset antal virtuelle ting ad gangen. Brugerne kan således være motiverede til at opgive den eksklusive mulighed for at råde over en (mindre værdifuld) virtuel ting, hvis brugeren i forlængelse heraf kan tilegne sig en anden (mere værdifuld) virtuel ting. Der vil i sådanne tilfælde også være tale om en originær retserhvervelse, idet objektet ikke tilhørte en anden i erhvervelsesøjeblikket.

Ejendomsretten over en virtuel ting kan desuden opnås ved, at brugeren udfører en eller flere opgaver af underholdningsmæssig karakter. Hvis opgaven udføres succesfuldt, sker det ofte, at udvikleren overdrager en virtuelle ting til brugeren gennem en automatisk virkende proces. I dette tilfælde er der tale om en derivativ retserhvervelse, idet den sker ved succession i en allerede eksisterende ret. Den automatisk virkende proces kan kort beskrives som et hændelsesforløb, hvor udvikleren frembringer en ny virtuel ting for dernæst straks at foranledige en overdragelse af denne til brugeren.

En brugers ejendomsret over en virtuel ting kan ligeledes opstå ved, at der bliver indgået en privat viljeserklæring med en anden bruger om overdragelse af ejendomsretten. Der er også i sådanne tilfælde tale om en derivativ retserhvervelse, idet retten er afledt fra en anden brugers ejendomsret.

Det er et fællestræk for alle de beskrevne retsstiftende kendsgerninger, at de medfører, at brugeren tildeles eksklusive beføjelser til at råde over den virtuelle 
ting i enhver henseende med de indskrænkninger, der følger af anden aftale, love mv. Det kan derfor konkluderes, at virtuelle ting kan ejes, når de foreligger som objekter, der kan underkastes kontrol. ${ }^{22}$

At data er undergivet ejendomsret har muligvis stået i skyggen af de positivt afgrænsede rettigheder, som knytter sig til informationen, de immaterielle rettigheder og regler, som skal værne om fortrolige og personfølsomme oplysninger. $^{23}$

\section{Beskyttelsesinteressen}

En handlings strafværdighed beror normalt ikke på, hvilken teknologisk indretning, der er genstand for handlingen. Strafferetlige delikter er da også oftest rettet mod handlemåden og ikke karakteren af det involverede objekt. ${ }^{24}$ Det ses tydeligt af, at begrebet »ting«/»gjenstand « indgår i en række forskelligartede delikter, fx den danske straffelovs $\S 139$, stk. 2 , $\S 187-189$, og $\S 192$ b og norsk straffelov $1902 \S \S 93,132,147,153$, hvor tilsvarende forskelligartede beskyttelsesinteresser knytter sig til tingsbegrebet. Bestemmelser om bl.a. tyveri og underslæb skal overordnet set værne om det, der kan henføres til en persons formue. Beskyttelsesinteressen kan derfor angives som ejendomsretten over en persons aktiver.

Virtuelle ting kan sammenlignes med objekter, som strafferetten traditionelt yder beskyttelse. Digitale bøger (såkaldte e-bøger) er en elektronisk udgave af den tilsvarende, trykte papirudgave af bogen. Indholdsmæssigt er de to udgaver altså ens, og værdien er principielt den samme for køberen/læseren. Det fysiske eksemplar er selvsagt beskyttet mod tyveri. Det er imidlertid den samme beskyttelsesinteresse, som bliver krænket, hvis den elektroniske udgave bliver borttaget fra en, der har købt denne udgave af bogen.

Objekter i virtuelle verdener har det tilfælles med de måske mere velkendte elektroniske produkter fra forlags-, film-, og musikindustrien, at data er produktet. Data kan derfor rumme produkter, som straffeloven traditionelt beskytter ejendomsretten over.

Beskyttelsen bør ikke afhænge af, om tingen forudsætningsvis kræver lagringskapacitet. Nødvendigheden af lagringskapacitet er da heller ikke særegen for data, idet andre ting, der ikke er i en fast form, også kræver tilstedeværelse af en opbevaringsenhed for at kunne kontrolleres.

Efter gerningsmandens disposition er situationen også den samme, uanset det bemægtigede objekts fysiske sammensætning; nemlig at denne har opnået en uberettiget vinding gennem et tilsvarende formuetab for den forurettede. ${ }^{25} \mathrm{De}$ samme almenpræventive hensyn synes derfor at gøre sig gældende - uanset produktets fysiske fremtrædelsesform. 
Særligt på et punkt adskiller virtuelle ting sig dog fra almindeligt løsøre. Den virtuelle tings eksistens afhænger fuldt og helt af, at udbyderen stiller den virtuelle verden til rådighed. Hvis den virtuelle verden ophører med at eksistere, fx pga. udbyderens konkurs eller en ændret forretningsstrategi, ophører tillige brugerens eksklusive beføjelser over den virtuelle ting. Det må medgives, at situationen er speciel i forhold til fysiske genstande. Jeg mener imidlertid ikke, at denne omstædighed er fundamental for den strafferetlige vurdering. På trods af den latente mulighed for at den virtuelle verden ophører med at eksistere, er de virtuelle ting en del af brugernes virkelighed, og de disponerer økonomisk som om, at de bliver varigt ejere af de pågældende virtuelle ting. Dette afspejles direkte i den økonomiske værdi, som tingene kan omsættes til. I den føromtalte hollandske højesteretsdom lagde domstolen da også vægt på, at objekter i den pågældende virtuelle verden er af reel værdi for brugerne, og at de i sagen involverede personer »inderligt ønskede at besidde « de omhandlende virtuelle ting. ${ }^{26}$

Ejendomsretten kan på andre områder også være underlagt store begrænsninger, fx pga. aftaler, lovgivning eller objektets naturlige egenskaber. Disse begrænsninger kan eksempelvis skyldes aftaler om forkøbsret, natur- eller bygningsfredning og objektets naturlige undergang ( $\mathrm{fx}$ i relation til madvare og kæledyr).

Den potentielle mulighed for unormale driftsbetingelser ændrer ikke på, at gerningsindholdet i de strafferetlige delikter kan anses for opfyldt, hvis handlingen er fuldbyrdet, inden den normale drift ophører.

\section{Kan en virtuel ting karakteriseres eller sidestilles som en rørlig ting?}

De berigelsesforbrydelser, der beskytter mod retsstridig tilegnelse af ting, angiver eller sidestiller for dansk strafferets vedkommende objektet for forbrydelsen som en »rørlig ting«. For at undersøge om der er direkte hjemmel til straf, må det undersøges om data, der udgør en virtuel ting, kan omfattes eller sidestilles med det begreb, som straffeloven anvender. Straffeloven indeholder ikke en definition af begrebet, og undersøgelsen må derfor tage udgangspunkt i en naturlig, sproglig fortolkning.

En diskussion om begrebets udstrækning er væsentlig men kan ikke stå alene. Selvom det er betydningsfuldt at få lovens anvendte begreber og udtryk afklaret, er begrebsanalyser, der ikke tager hensyn til den sammenhæng, som begrebet indgår $\mathrm{i}$, sjældent videre oplysende, eftersom mange begreber ikke siger noget $\mathrm{i}$ sig selv. ${ }^{27}$ Man må derfor tillige være opmærksom på den beskyttelsesinteresse, som bestemmelserne er sat til at værne om, jf. det ovenstående. 


\subsection{Begrebet »ting"}

Begrebet »ting « bliver almindeligvis anvendt om »enkeltfænomener uden hensyn til dets (abstrakte ell. konkrete) væsen [...]; ofte om hvad man ikke kan ell. vil angive nærmere « ${ }^{28}$ Hvis en sådan forståelse af begrebet accepteres, er der tale om et dynamisk begreb, og der er således plads til en gradvis retsudvikling i takt med teknologiske nyskabelser. ${ }^{29}$ Begrebet må følgelig kunne omfatte fænomener, som lovgiver ikke havde kendskab til, da loven blev vedtaget. Det betyder, at selvom lovgiver umuligt har kunnet foregribe den teknologiske udvikling, vil ejendomsretten over fænomener, som opstår i takt med nye opfindelser og den teknologiske udvikling, være beskyttet, når blot forholdet er dækket af gerningsbeskrivelsen. ${ }^{30}$

Spørgsmålet er herefter, om begrebet, også omfatter virtuelle ting. Det er muligt med afsæt i betænkningerne om datakriminalite ${ }^{31}$ og it-kriminalitet, ${ }^{32}$ Europarådets Cybercrime-konvention ${ }^{33}$ og Rådets rammeafgørelse 2005/222/RIA af 24. februar 2005 om angreb på informationssystemer at konkludere, at domstolene i en kommende dansk straffesag kan nå til, at virtuelle ting er »ting«.

\subsubsection{Straffelovrådets betcenkning om datakriminalitet}

Det fremgår af Straffelovrådets betænkning om datakriminalitet fra 1985, at rådet fandt det mest sandsynligt, at data isoleret set kan være genstand for hærværk. ${ }^{34}$ Rådet udtalte i den forbindelse: »Det kan diskuteres, om man kan tale om beskadigelse eller ødelæggelse af en »ting«, når man alene tænker på det indgreb, der sker i systemets mindste enhed, hvor data lagres ved magnetisering af et felt og kan kaldes frem ved aktivering af dette. Straffelovrådet finder det mest sandsynligt, at dette spørgsmål ville blive besvaret bekræftende, såfremt det kom til en principiel afgørelse i en straffesag. Men spørgsmålet er næppe af stor praktisk betydning. Man kan nemlig opfatte forholdet således, at der ved ændring eller sletning af data sker en beskadigelse af den genstand, som er databærer, f.eks. et bånd eller diskette «. ${ }^{35}$

Hvis data isoleret set efter Straffelovrådets opfattelse (sandsynligvis) er en »ting « i hærværkssituationer, kan det samme objekt (sandsynligvis) også være en »ting « i tilfælde af tyveri, underslæb mv.

\subsubsection{Kritik af en afledet beskyttelse}

En afledet beskyttelse, som den Straffelovrådet lagde op til, blev afgørende for udfaldet af U1987.216Ø. Under behandling af sagen i første instans fandt byretten, »[...] at de EDB-programmer og EDB-registre, der under denne sag er blevet slettet eller flyttet, er »ting « i straffelovens $§ 291$ 's forstand allerede af den grund, 
at der er sket en beskadigelse af den genstand, der bærer de omhandlede data." Landsretten sondrede ej heller mellem det fysiske medie og data, men lagde i stedet vægt på helheden: »Landsretten finder, at databærende medier med indlagte data må anses for »ting «, således som dette begreb anvendes i straffelovens $\S 291 \ll$.

Den teknologiske udvikling har medført, at en sådan afledet beskyttelse i flere tilfælde ikke er tilfredsstillende. Med udbredelsen af internettet er det i dag almindeligt for både virksomheder og privatpersoner at udnytte de netværksbaserede muligheder, som gør det muligt at kunne anvende lagringskapacitet på enheder, som ikke ejes af brugeren. Det forekommer således jævnligt, at retten til data og lagringsmedie ikke tilkommer den samme person.

I de mangeartede situationer, hvor retten til data og lagringsmedie ikke tilkommer den samme person, virker det konstrueret at lade beskyttelsen af data afhænge af lagringsmediet. Hvis en gerningsmand vil ødelægge data på en server, er det ikke det it-udstyr, som kan ses med det blotte øje, der er objektet for forbrydelsen. Hvis data alene skulle have en afledet beskyttelse, ville det medføre det ejendommelige og ganske upraktiske resultat, at det i alle tilfælde er ejeren af lagringsmediet, der er den forurettede i sagen. ${ }^{36}$

Dertil kommer, at en sådan afledet beskyttelse ikke er tilstrækkelig i de tilfælde, hvor ødelæggelsen af data skyldes ejeren af lagringsmediet. Situationen kan fx opstå, hvis udvikleren af en virtuel verden - pga. en uoverensstemmelse mellem denne og en bruger - sletter de virtuelle ting, som brugeren ejer, og som af tekniske årsager er lagret hos udvikleren. I et sådant tilfælde kan der kun være tale om hærværk, hvis data har et selvstændigt strafferetligt værn uafhængigt af lagringsmediet.

\subsubsection{Cybercrime-konventionen og Rådets rammeafgørelse om angreb på informationssystemer}

I 2001 vedtog Europarådet Cybercrime-konventionen. Det er den første internationale konvention om forbrydelser, der begås via internettet og andre computernetværk. Det fremgår af præamblen, at formålet med konventionen er at føre en effektiv kriminalpolitik med henblik på at beskytte samfundet mod cyberkriminalitet, især ved at sikre vedtagelse af relevant lovgivning og fremme det internationale samarbejde.

Cybercrime-konventionen angiver i artikel 1 selvstændige definitioner for et »edb-system« og »elektroniske data«. Et edb-system er ifølge konventionen »enhver anordning eller gruppe af indbyrdes forbundne eller sammenhængende an- 
ordninger, hvoraf en eller flere udfører automatisk databehandling i henhold til et program «.

Elektroniske data er defineret som »enhver gengivelse af fakta, informationer eller begreber i en form, der er egnet til behandling i et edb-system, herunder et program, der er egnet til at få et edb-system til at udføre en funktion«.

Som det fremgår af definitionerne, anerkender konventionen den teknologiske og funktionsmæssige gensidige afhængighed mellem data og edb-system. Opdelingen af data hhv. edb-system er imidlertid gennemgående for hele konventionen. Denne søger således i særskilte artikler at beskytte mod uretmæssige indgreb i data hhv. indgreb i edb-systemer. Fx lyder konventionens artikel 4 om indgreb i data således: »Enhver part skal vedtage sådanne lovgivningsmæssige og andre foranstaltninger, der måtte være nødvendige for at fastsætte, at det er en strafbar handling i henhold til national ret forsætligt og uberettiget at beskadige, slette, forringe, ændre eller undertrykke elektroniske data. [...]

I forlængelse af Cybercrime-konventionen fremkom et af Justitsministeriet nedsat udvalg med en betænkning i Danmark om it-kriminalitet i 2002. Udvalget overvejede bl.a., om den teknologiske udvikling har medført, at der er et behov for at justere de strafferetlige regler. Om Cybercrime-konventionen konkluderede udvalget, at den $»[. .$.$] på det strafferetlige område helt overvejende [indeholder]$ krav om en kriminalisering, der harmonerer med den nugældende regulering i straffeloven $\ll .{ }^{37}$ Udvalgets overvejelser er relevante i nærværende sammenhæng, idet Cybercrime-konventionen som nævnt stiller krav om, at de deltagende lande kriminaliserer uberettiget beskadigelse og sletning af data i artikel 4. En afledet beskyttelse fra det databærende medie, som den Straffelovrådet, jf. det ovenstående, henviste til i 1985, kan næppe opfylde denne forpligtelse, bl.a. fordi data således ikke vil være tilstrækkeligt beskyttet i de mange tilfælde, hvor retten til data og lagringsmedie tilkommer to forskellige personer.

Derudover opdeler Cybercrime-konventionen indgreb i edb-systemers funktioner og indgreb i data i to selvstændige artikler, hvilket taler imod, at en afledet beskyttelse skulle være tilstrækkelig.

Indgreb i et edb-systems funktioner kan ifølge artikel 5 ske ved »at indlæse, overføre, beskadige, slette, forringe, ændre eller undertrykke elektroniske data«. Dette svarer til Straffelovrådets konklusion i 1985, hvori det blev fremført, at man kan anse lagringsmediet for beskadiget, hvis data slettes herfra.

Cybercrime-konventionen bestemmer dog også, at data isoleret set skal beskyttes, idet opdelingen mellem artikel $4 \mathrm{og}$ artikel 5 kun giver mening, såfremt data er beskyttet uafhængigt af lagringsmediet. Hvis data kun skulle ydes beskyttelse i kraft af sin tilknytning til lagringsmediet, ville artikel 4 være overflødig. 
Justitsministeriets udvalg anførte i sine forslag til ændringer af straffeloven, at »udvalget finder, at den gældende hærværksbestemmelse i straffelovens § 291 er tilstrækkeligt klart dækkende, og at der ikke er behov for ændringer af den bestemmelse $\ll .{ }^{38}$ I forlængelse heraf erklærede Justitsministeriet i det senere forslag til ændring af bl.a. straffeloven sig enig i, at pligten til at kriminalisere forsætlig og uretmæssig sletning, ændring, beskadigelse mv. af data i medfør af Cybercrime-konventionen må anses for opfyldt ved bestemmelsen i straffelovens $§ 291$, stk. $1 .^{39}$

Den retskildemæssige værdi af Cybercrime-konventionen må ses i sammenhæng med, at lovgiver har baseret sine initiativer på indholdet af konventionen, herunder at konventionen var bilagt lovforslaget.

Formålet med lovforslaget var - udover at gøre det muligt for Danmark at ratificere Cybercrime-konventionen - desuden, at Danmark kunne deltage i vedtagelsen af »Rådets rammeafgørelse 2005/222/RIA af 24. februar 2005 om angreb på informationssystemer«. I lighed med Cybercrime-konventionen opdeler rammeafgørelsen »indgreb i informationssystemer« og »indgreb i data« i to særskilte artikler. Artikel 4 forpligter »medlemsstaterne til at [træffe] de nødvendige foranstaltninger for at gøre det strafbart forsætligt og uretmæssigt at slette, beskadige, forvanske, ændre, tilbageholde eller hindre adgang til edb-data i et informationssystem«. Det vil derfor heller ikke være foreneligt med denne rammeafgørelse, hvis data alene har en afledet beskyttelse. På grund af rammeafgørelsens bindende virkning for så vidt angår målet (modsat de konkrete midler), er det sandsynligt, at rammeafgørelsen vil indgå i fortolkningen af national ret - så længe ordlyden af de danske straffebestemmelser i øvrigt tillader det. ${ }^{40}$

Danske domstole kan således nå til, at data, herunder virtuelle ting, isoleret set er ting, der er beskyttet mod visse formueforbrydelser, fx hærværk. Hvis domstolene modsat skulle nå til, at data kun har en afledet beskyttelse i kraft af sin tilknytning til et fysisk lagringsmedie, vil dette ikke være foreneligt med hverken Cybercrime-konventionen eller Rådets rammeafgørelse om angreb på informationssystemer.

\subsection{Begrebet »rørlig"}

I det ovenstående har der været fokuseret på, om virtuelle ting er »ting « i en strafferetlig sammenhæng. I det følgende vil det blive undersøgt, om begrebet »rørlig« udelukker en dansk strafferetlig beskyttelse. Problemstillingen er også relevant i forhold til norsk strafferet, idet objektet for et fx underslæb er en »løsøregjenstand «. 
Adjektivet »rørlig « indgår næppe hyppigt i nutidens almindelige sprogbrug. Det er blevet brugt om ting, »som man kan fjerne [eller] tage med $\operatorname{sig} \ll{ }^{41}$ Data kan »fjernes«, fx ved sletning eller flytning mellem to brugerkonti, eller »tages med « på mobile opbevaringsenheder. ${ }^{42}$

I Straffelovrådets betænkning om datakriminalitet noteres det imidlertid, at en rørlig ting er en fysisk genstand, der kan flyttes - »d.v.s. en genstand man kan tage og føle på, modsat en mundtlig fordring, en panteret, en brugsret, en ophavsret o.1. ${ }^{43}$

Straffelovrådets bemærkning om, at man skal kunne »tage og føle på« genstanden, kan umiddelbart betragtet tolkes således, at rådet ikke mente, at data isoleret set kan være genstand for fx tyveri, idet det fysiologisk er vanskeligt at anse data som et objekt, man sanseligt kan »tage og føle på«. Data er en række binære cifre, der er lagret på et medie. Mediet udgøres i skrivende stund typisk af en magnetisk overflade, der er inddelt $i$ et gitterværk af små arealer. Når data eksempelvis skrives på en harddisk, lagres der magnetiske signaler, som vanskeligt lader sig kvalificere som noget, man skal kunne »tage og føle på«.

Det kan dog ikke afvises, at det afgørende for Straffelovrådet har været at markere, at forudsætningen for, at en ting er rørlig, er, at den kan flyttes, ${ }^{44}$ og at henvisningen til, at det således må være en genstand, man kan tage og føle på, nævnes af fremstillingstekniske årsager og i lyset af samfundets teknologiske niveau på daværende tidspunkt. Straffelovrådet når da også frem til, at man »formentlig [må] konkludere, at kravet om borttagelse af en fremmed rørlig ting i $\S 276$ giver tyveribestemmelsen et meget mindre anvendelsesområde i dataforhold end bestemmelserne om brugstyveri, bedrageri og mandatsvig. « $^{45}$ Straffelovrådet afviser altså ikke en beskyttelse i dataforhold, men angiver derimod, at anvendelsesområdet (formentlig) er mindre end ved andre delikter på grund af kravet om »borttagelse af en fremmed rørlig ting «.

Det har selvsagt ikke været muligt for Straffelovrådet at forudse fremtidens tekniske muligheder; og særligt internettets udvikling og senere omfang har næppe været begribeligt i midten af 1980'erne. Det er naturligvis i denne sammenhæng, at man må læse bl.a. Straffelovrådets konklusioner.

Det ændrer dog ikke ved, at data ej heller i senere dansk juridisk litteratur er blevet beskrevet som noget rørligt. Således anfører fx Mads Bryde Andersen, at »den, der tilegner sig en diskette med et edb-program, begår tyveri, hvorimod den, der ulovligt henter programmet ned fra en hjemmeside, ikke gør det. Når data overføres, sker der en flytning (eller rettere »ommøblering «) af bits, hvorimod der ikke flyttes atomer (som jo netop er $»$ rørlig ting «) «. ${ }^{46}$ 
Analysen i Mads Bryde Andersens eksempel er uanfægtelig i de tilfælde, hvor data (uretmæssigt) duplikeres fra en hjemmeside; men argumentationen skal ikke nødvendigvis støttes på, om der er tale om et objekt i bits eller atomer. Det kan afvises, at der i eksemplet er tale om tyveri allerede af den grund, at der ikke sker en »borttagelse«, som tyveribestemmelsen objektivt set kræver. Der er derimod tale om, at data eftergøres på den persons computer, der henter programmet, og samtidig efterlades på den computer, hvorpå det indledningsvis var lagret. I en sådan situation kan der være tale om en immaterialretlig krænkelse.

Situationen er som udgangspunkt ikke den samme som i de tilfælde, hvor en virtuel ting borttages fra en brugers konto og flyttes over på en anden brugers konto. Selvom den tekniske proces kan minde om duplikation, er resultatet ikke det samme. I en virtuel verden efterlades data ikke på den brugerkonto, hvorpå det indledningsvis var lagret. Situationen er derfor forskellig fra det eksempel, som gives af Mads Bryde Andersen. I en vurdering af om en beskyttelsesinteresse er krænket, bør tekniske processer ikke efterlades unødig stor opmærksomhed. Hvis den tekniske proces øger antallet af datamanifestationer, er situationen omfattet af værnet af information i medfør af de ophavsretlige regler. Hvis den tekniske proces derimod medfører, at objektet overdrages fra en bruger til en anden, sker der en ændring af besiddelsesforholdet, og situationen er omfattet af de bestemmelserne, der skal værne om ejendomsretten.

Det fremgår ikke af forarbejderne til tyveribestemmelsen, at en »rørlig ting« afgrænses til genstande, man kan »tage og føle på«. Det forekommer derfor nærliggende at antage, at det alene har været det teoretiske udgangspunkt, at en ting kun kan være genstand for tyveri (og i så henseende beskyttet af den danske straffelov), hvis denne kan flyttes fra en persons varetægt. ${ }^{47}$ Det har dermed ikke været meningen at begrænse beskyttelsen til objekter, der har bestemte fysiske sammensætninger, egenskaber, tilstands- eller fremtrædelsesformer.

\subsection{Energimangde}

Den danske straffelovs $\S 276,2$. pkt. bestemmer bl.a., at energimængder, der er opbevaret »i andet økonomisk øjemed«, sidestilles som rørlige ting. Tilsvarende fremgår det af den norske straffelov $1902 \S 6$, at »[u]nder udtrykket Løsøregjenstand indbefattes [...] ogsaa enhver til Frembringelse af Lys, Varme eller Bevægelse fremstillet eller opbevaret $\mathrm{Kraft} \ll{ }^{48}$ Bestemmelserne støtter, at det næppe har været hensigten at begrænse den strafferetlige beskyttelse med naturvidenskabelige kriterier. 
Når en virtuel ting er lagret, bliver data opbevaret som en energimængde på udviklerens server. Opbevaringen sker i økonomisk øjemed i de tilfælde, hvor den virtuelle ting har en formueværdi.

Det danske straffelovråd anførte i betænkningen om datakriminalitet fra 1985, at energimængder i dataforhold næppe kan sidestilles med de typer af ydelser eller varer af økonomisk værdi, som straffelovens $\S 276,2$. pkt. tager sigte på. ${ }^{49}$ Synspunktet bygger på, at bestemmelsen ikke omfatter energimængder, der udløses ved aktivering af computerens elektronisk virkende funktioner. Ser man isoleret på den økonomiske værdi i maengden af lagret energi, forekommer argumentet fornuftigt. Argumentationen forekommer dog ikke rammende i sager, som drejer sig om virtuelle ting. Den økonomiske værdi i sådanne tilfælde ligger ikke i mængden af opbevaret energi men derimod i den sammenhoeng, hvori opbevaringen indgår. Det er i denne sammenhæng, energimængden giver mening og værdi. I den rette sammenhæng kan en lille mængde opbevaret energi være langt mere værdifuld end en større mængde opbevaret energi. Det kan fx være i situationer, hvor en virtuel ting optager meget lagringskapacitet grundet dens grafiske udformning. Dermed er denne virtuelle ting opbevaret som en »større« energimængde, men pga. dens store udbud i den virtuelle verden er tingen ikke videre økonomisk værdifuld. Omvendt kan en grafisk ukompliceret virtuel ting optage ganske lidt lagringskapacitet, hvilket kun kræver en »lille« opbevaret energimængde men pga. den store efterspørgsel og det ringe udbud på netop denne virtuelle ting, vil den til trods herfor have en stor økonomisk værdi.

Hvis en gerningsmand borttager en virtuel ting fra en brugerkonto for at skaffe sig vinding, kan strafskyld for dansk strafferets vedkommende derfor også støttes på straffelovens $\S 276,2$. kkt. $^{50}$ Det afgørende for kommende praksis bliver da, om domstolene anser en virtuel ting for en »rørlig ting « eller en »energimængde $\ll$.

\section{Konklusion}

Som bemærket i begyndelsen af artiklen er det dristigt at have klare forventninger til domstolenes fortolkning af de eksisterende bestemmelser i kommende sager, der vedrører virtuelle ting. Der ses dog ingen holdepunkter for på forhånd at udelukke, at danske domstole (ligesom de hollandske) vil kunne fortolke loven således, at fx tyveri- og underslæbsbestemmelserne kan anvendes på forhold, der vedrører virtuelle ting. 


\section{Noter}

1. Artiklen er udarbejdet, mens forfatteren forskede i it-kriminalitet ved Juridisk Institut, Aarhus Universitet. Forfatteren er i dag ansat ved Den Uafhængige Politiklagemyndighed.

2. Lehdonvirta, Vili og Mirko Ernkvist: Converting the Virtual Economy into Development Potential. Knowledge map of the virtual economy, Washington DC: The World Bank, 2011, s. $11 \mathrm{ff}$. For at kunne sætte omsætningen i et perspektiv, kan opmærksomheden henledes på, at denne allerede nu overstiger flere afrikanske landes bruttonationalprodukt og er på niveau med Estlands.

3. Ibid, s. 15 .

4. Friislund, Michael: »Danskere spiller »WOW« som aldrig før«, Berlingske, http://www.b.dk/danmark/danskere-spiller-wow-som-aldrig-foer. (Besøgt 09.03.2014)

5. Funk, Christian: »Online gaming fraud: the evolution of the underground economy«, Securelist, http://www.securelist.com/en/analysis/204792139/Online_gaming_fraud_the_evolution_of_ the underground_economy. (Besøgt 09.03.2014)

6. BQ9251 Hoge Raad, afsagt 31.01.2012.

7. Min oversættelse. Lovteksten lyder: »Hij die enig goed dat geheel of ten dele aan een ander toebehoort wegneemt, met het oogmerk om het zich wederrechtelijk toe te eigenen, wordt, als schuldig aan diefstal, gestraft met gevangenisstraf van ten hoogste vier jaren of geldboete van de vierde categorie«. Den hollandske tyveribestemmelse er fra år 1886. På grund af den i sagen fremsatte trussel henviser retten tillige til artikel 312.

8. Det er værd at bemærke, at Holland tillige har kriminaliseret eksempelvis ulovlig adgang til it-systemer (artikel 138 a) og databedrageri (indfortolkes i artikel 225). Domstolen finder imidlertid, at objektet er en »ting « og således omfattet af tyveribestemmelsen.

9. Strl.bet. 1912, mot. 2. Se desuden strl.bet. 1917, mot. 5 og strl.bet. 1923, mot. 10.

10. Waaben, Knud: Strafferettens almindelige del I. Ansvarslaereren, 5. udgave ved Lars Bo Langsted, København: Karnov Group Denmark, 2011, s. 89 ff.

11. Andersen, Mads Bryde: IT-retten, 2. udgave, København: Gjellerup, 2005, s. 724 f.

12. Rumbles: Wayne: »Theft in the Digital: Can you Steal Virtual Property?«, i The Canterbury Law Review, Christchurch: University of Canterbury, 2011, s. $360 \mathrm{ff}$.

13. Se fx Udsen, Henrik: De informationsretlige grundsatninger. Studier i informationsretten, København: Jurist- og Økonomforbundets Forlag, 2009, s. 33 ff.

14. Fx en aftalt tavshedspligt.

15. Cfr. Kruse, Fr. Vinding: Ejendomsretten, 1. udg., 2. del, København: Nyt Nordisk Forlag, 1929, s. 460, der nævner, at tilegnelse af udøvende kunstneres præstationer gennem optagelse på lydbånd skulle kunne straffes som tyveri. Vinding Kruse bemærker dog samme sted, at »da vi nu en Gang har særlige Regler om Tyveri af aandelig Ejendom i Forfatter- og Kunstnerloven, synes det dog naturligt at anvende denne«.

16. Jf. den latinske oprindelse af medium: »I midten «.

17. Sunde, Inger Marie: Automatisert inndragning, Oslo: AIT Oslo, 2011, s. 29.

18. Ibid, s. 155 om data som formuegode. Se tillige Andersen, Mads Bryde: IT-retten, 2. udgave, København: Gjellerup, 2005, s. 555 ff. om information som formuegode.

19. Strl.bet. 1923, mot. 11 nævner da også, at »Ved Udtrykket »fremstillet eller opbevaret Kraft« er udelukket den Kraft, der findes fri i Naturen«. På betænkningens tid kunne dette angå den kraft, der findes i vind og vandløb. 
20. Tilsvarende tilhører fisk og vildt i fri tilstand ikke nogen, før de indfanges eller ombringes. Først da er de under kontrol, og følgelig beskyttet som formuegode.

21. Andersen, Mads Bryde: IT-retten, 2. udgave, København: Gjellerup, 2005, s. 438 nævner, at hvis originalitetskravet er opfyldt, nyder sådanne frembringelser ophavsretlig beskyttelse som et selvstændigt værk. Der er tale om en beskyttelse af informationen.

22. En række udviklere forbeholder sig alle rettigheder til samtlige objekter i de respektive virtuelle verdener. Problemstillingen er på flere retsområder interessant, men den bevirker ikke, at berigelsesforbrydelserne ikke kan anvendes, da disse alene forudsætter, at objektet er ejet af en anden end gerningsmanden. Man kan selvsagt godt stjæle noget, som besiddes af en brugsretshaver.

23. Sunde, Inger Marie: Automatisert inndragning, Oslo: AIT Oslo, 2011, s. 170.

24. Ibid., s. $131 \mathrm{ff}$.

25. I samme retning Andersen, Mads Bryde: IT-retten, 2. udgave, København: Gjellerup, 2005, s. 737, der tillægger informationsvaerdien vægt, bl.a. hvis handlingen bevirker, at den bestjålne ikke længere kan anvende et it-program.

26. BQ9251 Hoge Raad, pkt. 3.5. og 3.6.

27. Frost, Kim: Informationsydelsen, København: Forlaget Thomson, 2002, s. 75 om informationsydelser som løsøre. Ross, Alf: »Tû-Tû« i Borum, O.A. m.fl. i Festskrift til professor, $d r$. juris Henry Ussing 5. maj 1951, København: Juristforbundet, 1951 s. 468 ff.

28. Opslag på »ting« i Juul-Jensen, Harald: Ordbog over det Danske Sprog, bind 23, København: Gyldendal, 1946.

29. I strl.bet. 1923, mot. 383 angives det som eneste fortolkningsbidrag, at »Ordet »Ting« omfatter saavel Løsøre som fast Ejendom[...]«. Motiverne vedrører hærværksbestemmelsen i udkastets $\S 265$.

30. I samme retning Sunde, Inger Marie: Automatisert inndragning, Oslo: AIT Oslo, 2011, s. $120 \mathrm{ff}$., der analyserer norsk ret.

31. Bet. 1032/1985.

32. Bet. $1417 / 2002$.

33. Europarådets konvention om IT-kriminalitet (ETS 185) af 23. november 2001.

34. Straffelovens $\S 291$, stk. 1 straffer »den, der ødelægger, beskadiger eller bortskaffer ting, der tilhører en anden « (min kursivering). Selvom bestemmelsen ikke er en berigelsesforbrydelse, er der alligevel et vist begrebsmæssigt sammenfald.

35. Bet. 1032/1985, s. 37.

36. Fvsa. det upraktiske i situationen henvises til påtalekompetencen i straffelovens $\S 305$, stk. 1 .

37. Bet. $1417 / 2002$, s. 138

38. Bet. 1417/2002, s. 122. Se tillige s. 157.

39. Folketingstidende 2003-04, A, s. 1818.

40. Fsva. fortolkning af national ret på baggrund af rammeafgørelser se Elholm, Thomas: »EUkonform fortolkning af national strafferet«, i Møller-Sørensen, Annette m.fl.: Jurist uden omsvøb. Festskrift til Gorm Toftegaard Nielsen, København: Christian Ejlers' Forlag, 2007, s. 113 f. Artiklen henviser bl.a. til C-105/03, præmis 43. Se i øvrigt KOM (2010) 517, artikel 16.

41. Opslag på »rørlig« i Juul-Jensen, Harald: Ordbog over det Danske Sprog, bind 18, København: Gyldendal, 1939. 
42. Data er da også på andre retsområder blevet karakteriseret som løsøre. Se fx Frost, Kim: Informationsydelsen, København: Forlaget Thomson, 2002, s. 132, og Lookofsky, Joseph: Understanding the CISG, Fourth (Worldwide) Edition, Alphen aan den Rijn: Kluwer Law International, 2012, s. 19 f. Se tillige Andersen, Mads Bryde: IT-retten, 2. udgave, København: Gjellerup, 2005, s. 846 f, der påpeger en uenighed i teorien fsva., om køb af information kan betragtes som løsørekøb.

43. Bet. 1032/1985, s. 30 .

44. Det vil sige, at den potentielt kan »borttages« i tilfælde af tyveri og »tilegnes« i tilfælde af bl.a. underslæb.

45. Bet. 1032/1985, s. 32 .

46. Andersen, Mads Bryde: IT-retten, 2. udgave, København: Gjellerup, 2005, s. 736 f.

47. I samme retning Goos, Carl: Den danske strafferets specielle del, anden del, Kjøbenhavn: Gyldendalske boghandels forlag, 1895, s. 318.

48. I Sverige er afledning af elektricitet selvstændig kriminaliseret i kapitel 8, § 10 .

49. Bet. 1032/1985, s. 34 .

50. Det kan anføres, at energimængden fortsat befinder sig på udviklerens udstyr, når en virtuel ting flyttes fra en brugerkonto til en anden brugerkonto. Det er imidlertid ikke et krav, at objektet helt fjernes fra området, før der er tale om et fuldbyrdet tyveri. Se fx U1968.253H. 